\title{
New record of an alien plant, Petrorhagia nanteuilii (Caryophyllaceae) in Korea
}

\author{
Jeong-Ki HONG, Sang Deog SHIM ${ }^{1}$, Hyun Sik KIM², Sunhee SIM⿻, \\ Chang Woo HYUN ${ }^{3}$ and Jung-Hyun KIM ${ }^{3 *}$
}

\author{
Animal and Plant Research Department, Nakdonggang National Institute of Biological Resources, Sangju 37242, Korea \\ ${ }^{1}$ Woori Botanical Garden, Gwangju 61431, Korea \\ ${ }^{2}$ Korea Gas Corporation (Citizen Researcher), Daegu 41062, Korea
}

${ }^{3}$ Plant Resources Division, National Institute of Biological Resources, Incheon 22689, Korea

(Received 2 November 2021; Revised 30 November 2021; Accepted 12 December 2021)

\begin{abstract}
Petrorhagia nanteuilii (Burnat) P. W. Ball \& Heywood (Caryophyllaceae), native to western Europe and western North Africa and an introduced or alien plant in South America, Australia, and Japan, was newly found in Gyeongsangnam-do, Korea. Petrorhagia is clearly distinguished from other genera by a bract at the base of calyx, which differs from Gypsophila L., and commissures at the sepals, which is different from Dianthus L. Petrorhagia nanteuilii grows on slopes and roadsides, suggesting that it is likely to have been introduced through the installation of green sites and road construction. A precise description, illustration, photographs, and a key to related genera and species is provided.
\end{abstract}

Keywords: alien plant, Caryophyllaceae, new record, Petrorhagia nanteuilii

Caryophyllaceae Juss., include approximately 3,000 species in about 100 genera (Hernández-Ledesma et al., 2015). The family has a primarily North Temperate distribution and a diversity center in the eastern Mediterranean and Irano-Turanian regions. Its presence in the tropics and the southern hemisphere is limited and mostly confined to higher elevations (Bittrich, 1993; Rabeler and Hartman, 2005; Greenberg and Donoghue, 2011). Approximately 86 species of Caryophyllaceae, distributed among 17 genera (Hong and Choi, 2018), are in Korea. Kang et al. (2020) have reported 619 alien plants in Korea, including 21 taxa in the Caryophyllaceae.

Petrorhagia (Ser.) Link is a genus of 33 species distributed in the Mediterranean region, Europe and Western Asia (Ball and Heywood, 1964; Rabeler, 1985). In the past, it was considered to be part of such genera as Dianthus L., Gypsophila L., Kohlrauschia Kunth, and Tunica Scop. (Trigas et al., 2018). Evidence from both traditional and phylogenetic systematics supports its recognition as a distinct genus which is sister to a clade including Dianthus and Velezia L. (Ball and Heywood,
1964; Rabeler and Hartman, 2005; Greenberg and Donoghue, 2011; Trigas et al., 2018).

We here report the first occurrence of Petrorhagia, represented by $P$. nanteuilii in Korea (Figs. 1, 2). The Korean name for the genus is given as 'Pae-raeng-i-a-jae-bi-sok'.

During a field survey of plant diversity in Gyeongsangnamdo, we found the unrecorded alien plant, Petrorhagia nanteuilii, in abandoned fields and roadsides in Goseong-gun, Korea. We here provide a description, illustrations, a taxonomic key to related taxa as well as habitat details.

\section{Taxonomic Treatment}

\section{Description of the genus}

Petrorhagia (Ser.) Link, Handbuch 2: 235, 1831; Gypsophila sect. Petrorhagia Ser. in DC., Prodr. 1: 354, 1824.

Type species: Petrorhagia saxifraga (L.) Link, Handbuch 2: 235, 1831.-TYPE: not cited.

\footnotetext{
*Author for correspondence: kimjh4065@korea.kr
} 


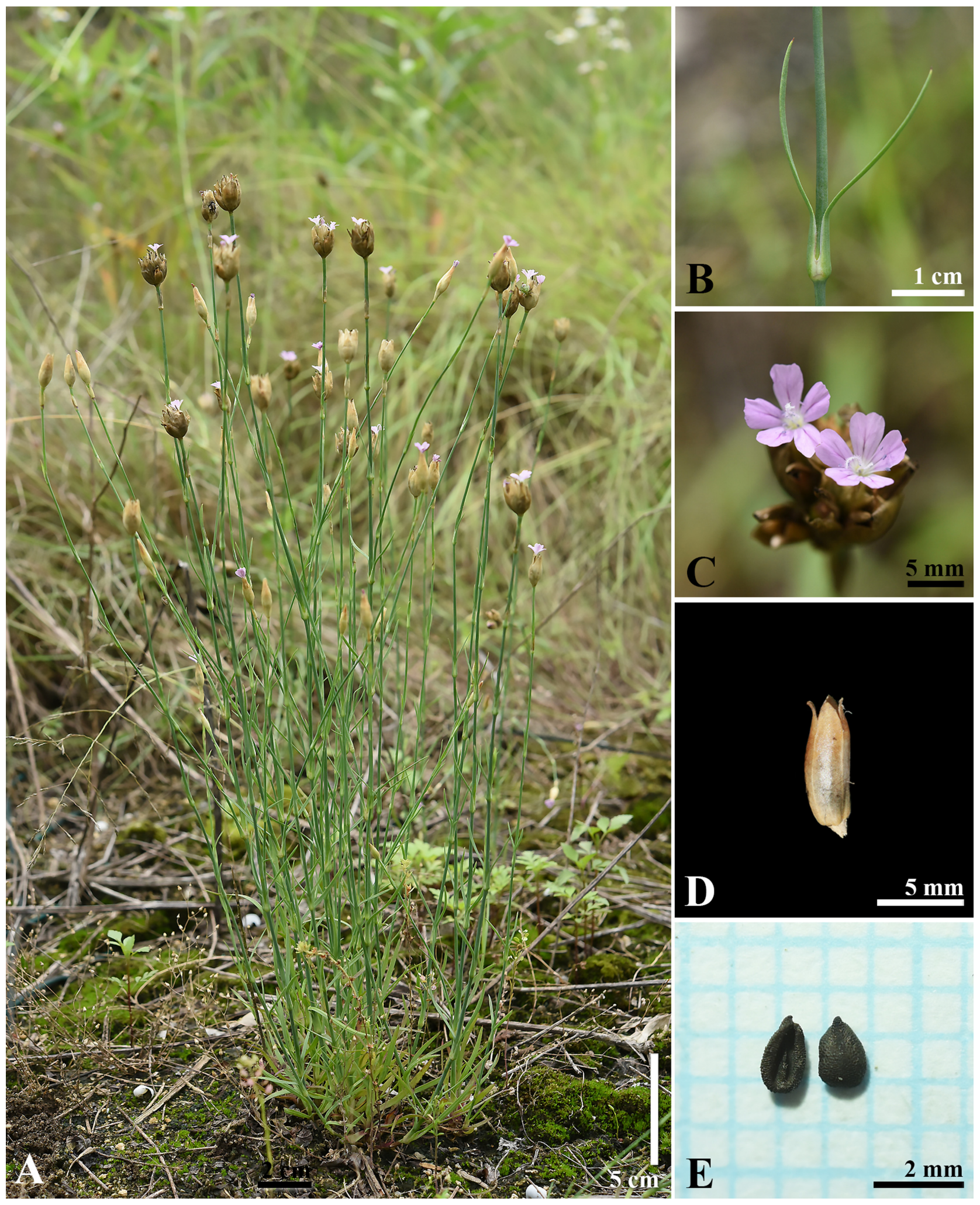

Fig. 1. Photographs of Petrorhagia nanteuilii (Burnat) P. W. Ball \& Heywood. A. Habit. B. Stem with leaf and sheath. C. Flowers (apical view). D. Capsule. E. Seeds. 
Korean name: Pae-raeng-i-a-jae-bi-sok (패랭이아재비속).

Herbs, annual or perennial, hermaphroditic, dioecious or gynodioecious. Stems erect or ascending, simple or branched, sometimes proximally woody. Leaves opposite, simple, sessile; blade linear to narrowly oblanceolate, apex acute, margins entire, both surfaces glabrous or scabrous, 1- or 3-veined. Inflorescences terminal, dense capitula or lax cymes or flowers solitary; bracts paired, often enclosing inflorescence; involucel bracteoles of 1-4 pairs or rarely absent. Flowers bisexual or unisexual; sepals basally connate, forming a tube, cylindrical, 15-veined, green or reddish and white or brown, scarious; lobes green, reddish, or brown, 3-veined, oblong, shorter than tube, margins white or brown, scarious, apex rounded; petals 5, pink, purplish or white, clawed, auricles absent, coronal appendages absent, apex entire, obtuse or 2-fid; stamens 10; filaments
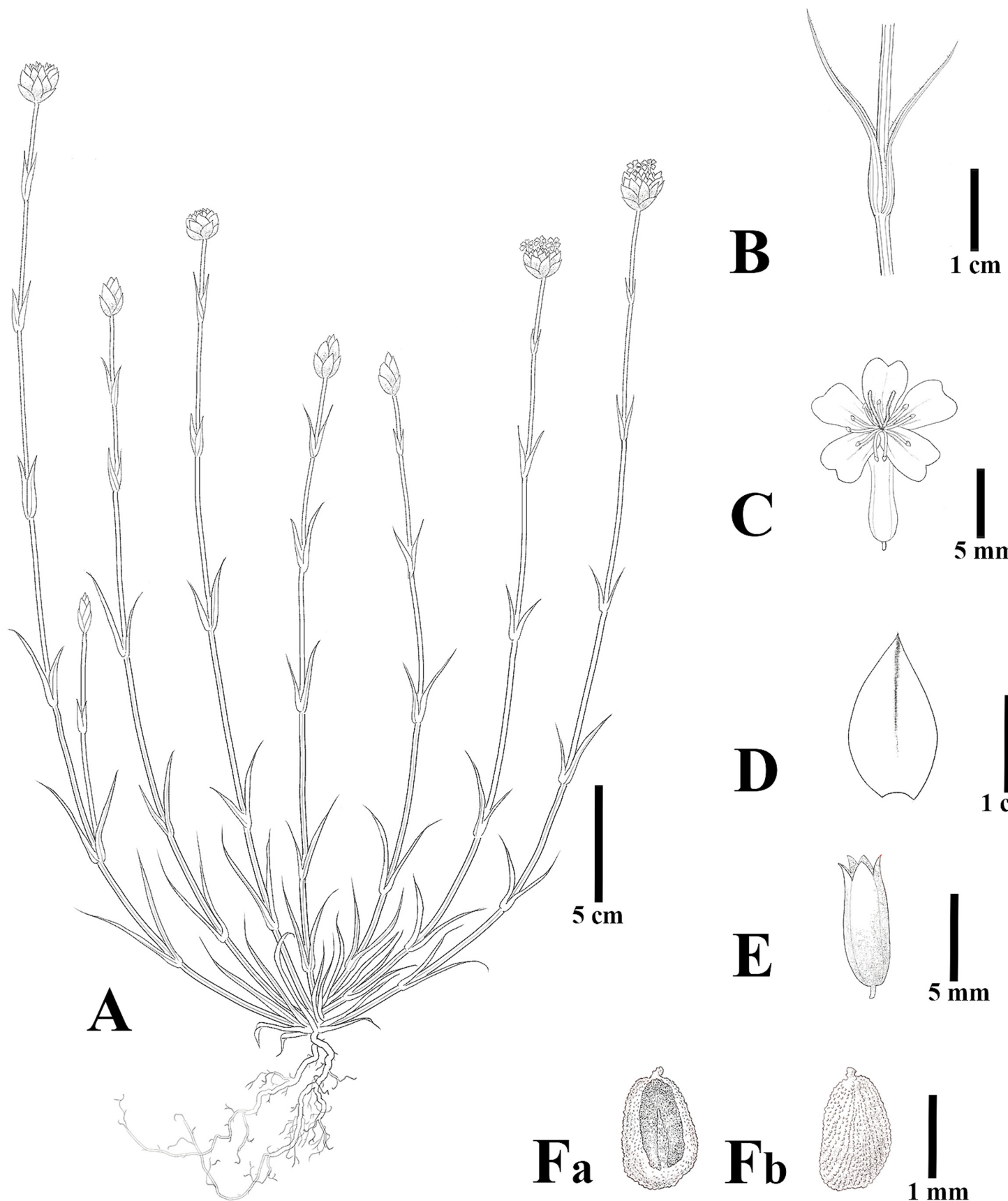

C

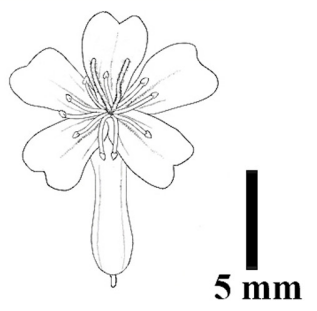

D
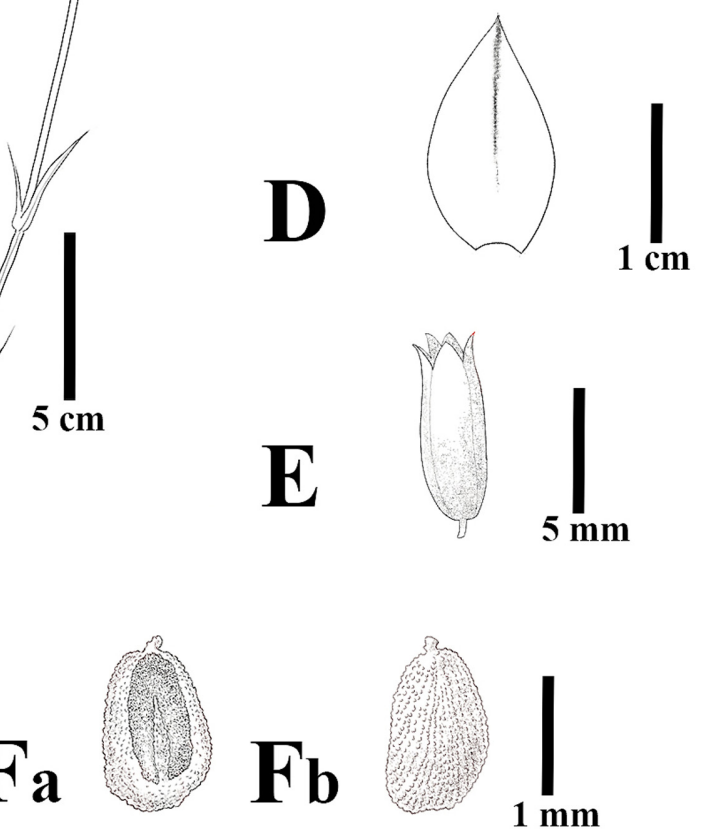

Fig. 2. Illustrations of Petrorhagia nanteuilii (Burnat) P. W. Ball \& Heywood. A. Habit. B. Stem with leaf and sheath. C. Flower (apical view). D. Involucral bract. E. Capsule. F. Seeds (a, ventral view; b, dorsal view). 
distinct; staminodes absent; ovary 1-locular; styles 2; filiform; stigmas 2 , linear, along adaxial surface of styles, papillate. Fruit capsules, 4-lobed, oblong, shorter than sepals. Seeds 8-15, blackish brown, shield- or helmet-shaped, dorsiventrally compressed, reticulate or papillate, marginal wing absent, embryo central, straight.

\section{Key to Petrorhagia and related taxa in Korea}

1. Bracts absent at base of calyx ‥ Gypsophila 대나물속

1. Bracts present at base of calyx.

2. Commissures between adjacent sepals present; veins per sepal 1-3 ……… Petrorhagia 패랭이아재비속

2. Commissures between adjacent sepals absent; veins per sepal 5 or more ………… Dianthus 패랭이꽃속

\section{Description of the species}

Petrorhagia nanteuilii (Burnat) P. W. Ball \& Heywood, Bull. Brit. Mus. (Nat. Hist.), Bot. 3: 164, 1964; Dianthus nanteuilii Burnat, Fl. Alpes Marit. 1: 221, 1892 (Figs. 1, 2).TYPE: not cited.

Korean name: Pae-raeng-i-a-jae-bi (패랭이아재비).

Herbs, annual, 20-50 cm tall, glabrous, or partly tomentose. Stems erect, simple or branched; internodes glabrous or mid stem and proximal ones minutely stipitate glandular. Leaves opposite, simple, sessile; blade linear, 1-3 cm long, apex acute, margins scabrous, 3-veined; sheath 1-2(-3) mm long, 1.5-2 times longer than wide. Inflorescences terminal, capitate; inflorescence bracts and involucel bracteoles enclosing flowers, broadly ovate, brown scarious, apex of outer bracts mucronate, inner bracts obtuse or mucronate; pedicels $0.1-2 \mathrm{~mm}$ long. Flowers: calyx 5-10 mm long, calyx-lobes obtuse, membranous; petals pink or purplish, 5-10 mm long, primary veins 3 , central vein darkly colored near base of blade, apex obcordate or 2fid; stamens 10, slightly exserted; styles 2 , exserted. Capsules ellipsoid-ovoid, ca. $6 \mathrm{~mm}$ long. Seeds brownish black, shield shaped, 1-1.5 mm long, tuberculate.

Flowering: May to June.

Fruiting: June to July.

Distribution: Korea, Asia, Australia, South America, western Europe, western North Africa

Specimens examined: KOREA. Gyeongsangnam-do: Goseong-gun, Goseong-eup, Su-nam-ri, 13 Jun 2020, Hyun Sik Kim KIMJH20155, KIMJH20156, KIMJH20157, KIMJH20158 (KB); same locality, 17 Jun 2021, Jung-Hyun Kim \& Seog
Table 1. Classification of invasive alien plants in Korea.

\begin{tabular}{ccc}
\hline \hline Grades of spread & Classification & No. of places \\
\hline V (WS) & Widespread & $>100$ \\
IV (SS) & Serious spread & $75-100$ \\
III (CS) & Concerned spread & $50-74$ \\
II (MS) & Minor spread & $25-49$ \\
I (PS) & Potential spread & $<25$ \\
\hline
\end{tabular}

woo Kwon KIMJH21089, KIMJH21090, KIMJH21091, KIMJH21092, KIMJH21093, KIMJH21094 (KB); same locality, 20 Jun 2021, Sang Deog Shim \& Hyun Sik Kim KIMJH21095, KIMJH21096, KIMJH21097 (KB).

Notes: Petrorhagia nanteuilii is native in western Europe and western North Africa, whereas it is an alien in South America, Australia, and Japan (Osada, 1972, 1989; Auld et al., 2003; Shimizu, 2003; Rabeler and Hartman, 2005). It may be an alloploid derived through hybridization between P. prolifera and P. dubia in Europe (Thomas and Murray, 1983). We first found P. nanteuilii on roadsides in Goseong-gun, Gyeongsangnam-do, in Korea in 2019 and confirmed its presence during the flowering seasons of 2020 and 2021. The population was composed of 2,000 individuals within an area of $50 \times 20 \mathrm{~m}^{2}$. The canopy vegetation included Ulmus pumila L.; the herbaceous vegetation was made up of Stellaria alsine var. undulata (Thunb.) Ohwi, Lespedeza cuneata (Dum. Cours.) G. Don., Medicago lupulina L., Vicia sativa subsp. nigra (L.) Ehrh., Oenothera biennis L., Erodium cicutarium Willd., Torilis japonica (Houtt.) DC., Metaplexis japonica (Thunb.) Makino, Amethystea caerulea L., Veronica persica Poir., Bidens pilosa L., Coreopsis lanceolate L., Erigeron annuus (L.) Pers., Bromus japonicas Thunb., Eragrostis curvula (Schrad.) Nees, and Setaria viridis (L.) P. Beauv.

Thousands of individuals of Petrorhagia nanteuilii now grow at high density in the site where it was found. Additional populations will probably be discovered. According to the invasive grades (Table 1) categorized by Jung et al. (2016), $P$. nanteuilii is classified as a potential invasive species, since no additional sites have been found. Nevertheless, considering its population size and rate of seed set, a grade adjustment may be necessary in the future due to its spread.

ORCID: Jeong-Ki HONG https://orcid.org/0000-0002-54508331; Sang Deog SHIM https://orcid.org/0000-0002-74373972; Sunhee SIM https://orcid.org/0000-0001-9788-7653; Chang Woo HYUN https://orcid.org/0000-0001-9677-5270; Jung-Hyun KIM https://orcid.org/0000-0003-2699-5635 


\section{Acknowledgments}

We are gareful to two anonymous reviewers and David Boufford of Harvard University Herbaria for their helpful comments and suggestions. This work was supported by a grant from the National Institute of Biological Resources (NIBR) and Nakdonggang National Institute of Biological Resources (NNIBR), funded by the Ministry of Environment (MOE) of the Republic of Korea (NIBR202102103 and NNIBR202101101).

\section{Conflicts of Interest}

The authors declare that there are no conflicts of interest.

\section{Literature Cited}

Auld, B., H. Morita, T. Nishida, M. Ito and P. Michael. 2003. Shared exotica: Plant invasions of Japan and south eastern Australia. Cunninghamia 8: 147-152.

Ball, P. W. and V. H. Heywood. 1964. A revision of the genus Petrorhagia. Bulletin of the British Museum (Natural History), Botany 3: 119-172.

Bittrich, V. 1993. Caryophyllaceae Juss. In Families and Genera of Vascular Plants 2. Kubitzki K., J. G. Rohwer and V. Bittrich (eds.), Springer Verlag, Berlin and New York. Pp. 206-236.

Greenberg, A. K. and M. J. Donoghue. 2011. Molecular systematics and character evolution in Caryophyllaceae. Taxon 60: 1637-1652.

Hernández-Ledesma, P., W. G. Berendsohn, T. Borsch, S. Von Mering, H. Akhani, S. Arias, I. Castañeda-Noa, U. Eggli, R. Eriksson, H. Flores-Olvera, S. Fuentes-Bazán, G. Kadereit, C. Klak, N. Korotkova, R. Nyffeler, G. Ocampo, H. Ochoterena, B. Oxelman, R. K. Rabeler, A. Sanchez, B. O. Schlumpberger and P. Uotila. 2015. A taxonomic backbone for the global syn- thesis of species diversity in the angiosperm order Caryophyllales. Willdenowia 45: 281-383.

Hong, S-P. and K. Choi. 2018. Caryophyllaceae Juss. In Flora of Korea. Vol. 3. Caryophyllidae. Flora of Korea Editorial Committee (ed.), National Institute of Biological Resources, Incheon. Pp. 30-61.

Jung, S. Y., J. W. Lee, Y. H. Kwon, H. T. Shin, S. J. Kim, J. B. An and T. I. Heo. 2016. Invasive Alien Plants in South Korea. Korea National Arboretum, Pocheon, 265 pp. (in Korean)

Kang E. S., S.-R. Lee, S. H. Oh, D.-K. Kim, S.-Y. Jung and D. C. Son. 2020. Comprehensive review about alien plants in Korea. Korean Journal of Plant Taxonomy 50: 89-119. (in Korean)

Osada, T. 1972. Illustrated Japanese Alien Plants. Hokuryu-kan Publishing Co., Ltd., Tokyo, 156 pp. (in Japanese)

Osada, T. 1989. Colored Illustrations of Naturalized Plants of Japan. 8th ed. Hoikusha Publishing Co., Ltd., Osaka, 308 pp. (in Japanese)

Rabeler, R. K. 1985. Petrorhagia (Caryophyllaceae) of North America. SIDA 11: 6-44.

Rabeler, R. K. and R. L. Hartman. 2005. Petrorhagia. In Flora of North America. Vol. 5. Magnoliophyta: Caryophyllidae, Part 2. Flora of North America Editorial Committee (ed.), Oxford University Press, New York, NY. Pp. 162-165.

Shimizu, T. 2003. Naturalized Plants of Japan. Heibonsha Ltd., Tokyo, 56 pp. (in Japanese)

Thomas S. M. and B. G. Murray. 1983. Chromosome studies in species and hybrids of Petrorhagia sect. Kohlrauschia (Caryophyllaceae). Plant Systematics and Evolution 141: 243-255.

Trigas P., K. Kougioumoutzis, A. Ermidou and E. Kalpoutzakis. 2018. Multivariate morphometric analysis of Petrorhagia subsect. Saxifragae (Caryophyllaceae) in Greece, with a new species from SE Peloponnisos: P. laconica. Willdenowia 48: $137-$ 146. 